Cite this: Analyst, 2013, 138, 2104

Received 17th October 2012

Accepted 1st February 2013

DOI: 10.1039/c3an36508e

www.rsc.org/analyst

\title{
Kinetic analysis of renin and its inhibitors by detecting double-labelled peptidic substrates with an immunoassay $\dagger$
}

\author{
Hans H. Gorris* \\ The proteolytic activity of renin is a key element in the regulation of blood pressure and a main target for \\ inhibitor design. Currently, the activity of renin and its inhibitors is mainly analyzed using \\ radioimmunoassays or FRET-substrates, which both have their limitations. Here, a novel kinetic assay is \\ presented that combines the advantages of a homogeneous proteolytic reaction and a robust \\ heterogeneous detection in a sandwich immunoassay format. The proteolysis in solution is not \\ influenced by surface interactions and yields accurate kinetic values, while the specific detection of the \\ cleavage products on a microtiter plate strongly reduces interference by concomitant substances and \\ allows for a self-referenced signal readout. A new enzyme kinetic scheme for the inhibition of renin has \\ been developed and validated by using the model inhibitor pepstatin. This kinetic analysis is amenable \\ to parallelization for large-scale inhibitor screening. Furthermore, it can be easily adapted to inhibitors \\ of other medically important proteases.
}

\section{Introduction}

Renin is a monomeric $37 \mathrm{kDa}$ aspartyl-protease that initiates the renin-angiotensin system (RAS). This protease cascade regulates homeostatic processes, such as blood pressure and fluid volume, but is also involved in the development and progression of fibrotic and hypertrophic diseases. ${ }^{1}$ Renin is released from the kidneys into the circulation and specifically cleaves the N-terminal part of the $50 \mathrm{kDa}$ glycoprotein angiotensinogen. The N-terminal decapeptide angiotensin I is further processed by angiotensin-converting enzyme (ACE) to the octapeptide angiotensin II. By binding to the $\mathrm{AT}_{1}$ receptor, angiotensin II induces vasoconstriction as well as renal sodium and water retention, which increase blood pressure. In particular, the central role in the regulation of blood pressure has urged the development of drugs that inhibit RAS compounds. Renin, the first and rate-limiting step of the RAS, has long been considered as the preferable target for inhibition. ${ }^{2}$ Until recently, however, only $\mathrm{ACE}$ inhibitors or $\mathrm{AT}_{1}$ receptor blockers were available for the treatment of hypertension that are implicated in adverse effects. ${ }^{3}$ For example, ACE inhibitors also inhibit the proteolysis of bradykinin, which may result in cough and angioedema, and angiotensin II can still be produced by other proteases. The action of angiotensin II, on the other hand,

Institute of Analytical Chemistry, Chemo- and Biosensors, University of Regensburg, D-93040 Regensburg, Germany. E-mail: Hans-Heiner.Gorris@ur.de; Fax: +49-941943-4064; Tel: +49-941-943-4008

† Electronic supplementary information (ESI) available: Analysis of renin in murine plasma samples. See DOI: 10.1039/c3an36508e cannot be completely suppressed by $\mathrm{AT}_{1}$ blockers as it can bind to different receptor subtypes. Consequently, when the first orally available renin inhibitor aliskiren was approved in 2007, it was considered an important hallmark in the more than 100 year-old history of renin and sparked renewed interest in its activity and inhibition. ${ }^{4}$

Haber et al. ${ }^{5}$ introduced the first reliable radioimmunoassay for measuring the activity of plasma renin in 1969 that - in different variations - is still widely used today. ${ }^{6}$ For this competitive immunoassay, the product angiotensin $\mathrm{I}$ is captured by an immobilized antibody. Then, the radiolabeled angiotensin I is added, which binds to the remaining free sites of the capture antibody and can be measured with a scintillation counter. To avoid radioactive materials other - mainly homogeneous - assay formats have been developed, e.g. based on HPLC-electrospray-tandem mass spectrometry, ${ }^{7}$ fluorogenic substrates $^{8-10}$ or FRET. ${ }^{11-13}$ For fluorogenic substrates, however, a fluorophore must be placed next to the cleavage site, and FRET substrates are only quenched efficiently if the distance between the donor and acceptor is typically in the range of 2 to $6 \mathrm{~nm} .{ }^{14}$ In particular, peptidic substrates of renin that are derived from the large protein sequence of angiotensinogen require long sequences of at least eight amino acids to show significant hydrolysis rates,$^{15}$ and considerable effort has been devoted to identifying good FRET substrates. ${ }^{13}$

We have recently introduced a new stability test for peptides that imposes no restriction on the length of the amino acid sequence and combines the advantages of homogeneous and heterogeneous assay formats. ${ }^{16}$ First, double-labelled peptides are subjected to proteolytic degradation in solution (homogeneous 
phase). The peptide is then transferred and immobilized on a microtiter plate via its $\mathrm{N}$-terminal label. ${ }^{\mathbf{1 7}}$ If the peptide has not been cleaved, the C-terminal label binds to an enzymeamplified detection system. If the peptide has been cleaved, by contrast, it does not contain the C-terminal label and no signal is observed. The ratio of cleaved to uncleaved peptide defines the stability of the peptide in a biological sample. Here, we employ this detection scheme to accurately determine the proteolytic activity of renin in parallel, and demonstrate how it can be used to elucidate renin-inhibitor interactions with the model inhibitor pepstatin. ${ }^{18-20}$

\section{Experimental}

\section{Buffers and reagents}

L(ite)-PBS: $10 \mathrm{mM}$ sodium phosphate, $\mathrm{pH} 7.0,10 \mathrm{mM} \mathrm{NaCl}$; D(ulbecco's)-PBS: $2.7 \mathrm{mM} \mathrm{KCl,} 1.5 \mathrm{mM} \mathrm{KH}_{2} \mathrm{PO}_{4}, 136 \mathrm{mM} \mathrm{NaCl}$, $8.1 \mathrm{mM} \mathrm{Na}_{2} \mathrm{HPO}_{4}$, pH 7.3; maleate buffer: $50 \mathrm{mM}$ maleic acid, $33.5 \mathrm{mM}$ Tris, $10 \mathrm{mM}$ EDTA, adjusted to $\mathrm{pH} 6.0$ with $\mathrm{NaOH}$. The monoclonal anti-2,4-D antibody clone E2/G2 was a kind gift from Milan Fránek. ${ }^{21}$ Recombinant human renin $\left(50 \mu \mathrm{g} \mathrm{ml}{ }^{-1}\right.$ in $50 \mathrm{mM}$ aqueous 3-( $N$-morpholino)propanesulfonic acid, $\mathrm{pH}$ 7.0) was purchased from Anaspec (http://www.anaspec.com); horseradish peroxidase-labelled streptavidin (SA-HRP, $1 \mathrm{mg}$ $\mathrm{ml}^{-1}$ in $50 \mathrm{mM} \mathrm{NaHCO}, \mathrm{pH}$ 8.3) from Vector Laboratories (http://www.vectorlabs.com); pepstatin from Roche (http:// www.roche.de); and 3,3',5,5'-tetramethylbenzidine (1-Step ${ }^{\mathrm{TM}}$ Ultra TMB-ELISA) from Pierce Biotechnology (http:// www.piercenet.com).

\section{Peptide synthesis of renin substrates}

Peptides were synthesized on a tentagel amide resin $(0.24 \mathrm{mmol}$ $\mathrm{g}^{-1}$; Intavis, http://www.intavis.com) at room temperature (rt) using standard fluorenylmethoxycarbonyl (Fmoc) protection chemistry and an automated multiple peptide synthesizer (MultiPep RS, Intavis). First, $1.3 \mathrm{~g}$ of the resin was swollen in 50 $\mathrm{ml}$ of a solvent mixture $(7: 3, \mathrm{v} / \mathrm{v})$ of dichloromethane and dimethylformamide (DMF). Then, $3 \mu \mathrm{mol}$ of the resin were transferred to wells of a filter bottom microtiter plate (Intavis, 96 well reaction plate, $2-5 \mu \mathrm{mol}$ ) and washed three times with $300 \mu \mathrm{l}$ of DMF. The resin was Fmoc-deprotected two times for 5 min with $170 \mu \mathrm{l}$ of $20 \%(\mathrm{v} / \mathrm{v})$ piperidine in $\mathrm{DMF}$, and washed ten times with $250 \mu \mathrm{l}$ of DMF. A solvent mixture of $24 \mu \mathrm{l}$ of $0.6 \mathrm{M}$ Fmoc-amino acid (Iris Biotech, http://www.iris-biotech.de) in DMF, $8 \mu \mathrm{l}$ of $4 \mathrm{M}$ 4-methylmorpholine in DMF, and $23 \mu \mathrm{l}$ of 0.6 M 2-(1H-benzotriazol-1-yl)-1,1,3,3-tetramethyluronium hexafluorophosphate (Iiris Biotech) in DMF was applied to the resin two times for $30 \mathrm{~min}$. The resin was washed three times with $300 \mu \mathrm{l}$ of DMF, incubated for 5 min with $120 \mu \mathrm{l}$ of $5 \%(\mathrm{v} / \mathrm{v})$ acetic anhydride in DMF to acetylate unreacted terminal amino groups, and washed six times with $250 \mu \mathrm{l}$ of DMF. The synthesis cycles were repeated to assemble individual peptides in each well. After a final deprotection step, the resin was washed ten times with $250 \mu \mathrm{l}$ of DMF. Terminal amino groups of the peptides were acetylated by adding two times $120 \mu \mathrm{l}$ of $5 \%$ acetic anhydride (v/v) in DMF for 5 min. The resin was washed eight times with $250 \mu \mathrm{l}$ of DMF, and six times with $150 \mu \mathrm{l}$ of dichloromethane. After extracting for $5 \mathrm{~min}$, the resin was dried in vacuo for $12 \mathrm{~h}$. The resin was incubated for $10 \mathrm{~min}, 30 \mathrm{~min}$ and 90 min with $100 \mu \mathrm{l}$ of a solvent mixture (v/v) of $92.5 \%$ trifluoroacetic acid, 5\% triisobutylsilane, and $2.5 \%$ water to release the peptides into solution, which was then collected in a 96-well plate (MegaBlock, Sarstedt, http:/www.sarstedt.com) and dried in vacuo. The peptides were incubated with $1250 \mu \mathrm{l}$ of cold methyl tert-butyl ether for $12 \mathrm{~h}$, the supernatants were removed, and the peptides were dried in vacuo. A stock solution of $3 \mathrm{mM}$ peptide in DMF was prepared and analyzed by reversed phase HPLC (HP Agilent 1100, http:/www.chem.agilent.com)/ electrospray ionization mass spectrometry (ThermoQuest Finnigan TSQ 7000, Finnigan, Bremen, Germany). For further experiments, the peptide was first diluted to $100 \mu \mathrm{M}$ in ethanol and then to $1 \mu \mathrm{M}$ in L-PBS $\times 0.005 \%(\mathrm{w} / \mathrm{v})$ Tween 20 .

\section{Capture ELISA}

High-bind 96-well microtiter plates (Corning, http:// www.corning.com) were coated overnight at $4{ }^{\circ} \mathrm{C}$ with $75 \mu \mathrm{l}$ per well of $150 \mathrm{ng} \mathrm{ml}^{-1}$ anti-2,4-D antibody in L-PBS. After three washing steps using $300 \mu \mathrm{l}$ of D-PBS $\times 0.05 \%(\mathrm{w} / \mathrm{v})$ Tween $20(\mathrm{D}$ PBST), the plates were blocked for 3-4 h at rt with $250 \mu \mathrm{l}$ of $1 \%$ (w/v) casein in D-PBS, and again washed four times with D-PBST. Peptides 1, 2 and 3 were serially diluted in $50 \mu \mathrm{l}$ of maleate buffer $\times 0.005 \%(\mathrm{w} / \mathrm{v})$ Tween 20 . After $2 \mathrm{~h}$ and $30 \mathrm{~min}$, the plates were washed four times with D-PBST and incubated for $60 \mathrm{~min}$ at rt using $75 \mu \mathrm{l}$ of $1 \mu \mathrm{g} \mathrm{ml} \mathrm{m}^{-1} \mathrm{SA}-\mathrm{HRP}$ in $1 \%(\mathrm{w} / \mathrm{v})$ casein in D-PBS. The plates were washed six times with D-PBST and developed with $75 \mu \mathrm{l}$ of tetramethylbenzidine. The colour development was terminated after $30 \mathrm{~min}$ by adding $125 \mu \mathrm{l}$ of 1 $\mathrm{M} \mathrm{H}_{2} \mathrm{SO}_{4}$, and the absorption was measured at $\lambda=450 \mathrm{~nm}$ using a microtiter plate reader. The software GraphPad Prism 5 was used to fit the data curves.

\section{Renin assay}

The proteolytic reaction of renin was carried out in a 96-well polypropylene microtiter plate (Corning, http:// www.corning.com). Either a defined concentration of human renin or murine plasma samples were serially diluted in $50 \mu \mathrm{l}$ per well of $10 \mathrm{nM}$ peptide in maleate buffer $\times 0.005 \%(\mathrm{w} / \mathrm{v})$ Tween 20. For inhibition studies, constant concentrations of pepstatin were added to the peptide solution. The sealed microtiter plate was incubated for either $90 \mathrm{~min}$ or $20 \mathrm{~h}$ at $37^{\circ} \mathrm{C}$. The proteolytic reaction was terminated by adding $50 \mu \mathrm{l}$ of a 2 $\mu \mathrm{M}$ pepstatin solution and incubating on ice for $10 \mathrm{~min}$. From each cavity, $75 \mu \mathrm{l}$ of the peptide solution was transferred to a high-bind 96-well microtiter plate which beforehand had been coated with $75 \mu \mathrm{l}$ of $150 \mathrm{ng} \mathrm{ml}{ }^{-1}$ anti-2,4-D antibody, washed and blocked as described above. After $2 \mathrm{~h}$ and $30 \mathrm{~min}$ at $\mathrm{rt}$, the plate was washed four times with D-PBST, and incubated for 60 min at rt using $75 \mu \mathrm{l}$ of $1 \mu \mathrm{g} \mathrm{ml} \mathrm{m}^{-1}$ of horseradish peroxidaselabelled streptavidin in $1 \%(\mathrm{w} / \mathrm{v})$ casein in D-PBS. The plates were washed six times with D-PBST and developed with $75 \mu \mathrm{l}$ of tetramethylbenzidine. The colour development was terminated after 30 min by adding $125 \mu \mathrm{l}$ of $1 \mathrm{M} \mathrm{H}_{2} \mathrm{SO}_{4}$, and the absorption 
was measured at $\lambda=450 \mathrm{~nm}$ with a microtiter plate reader. The software GraphPad Prism 5 was used to fit the data curves.

\section{Results and discussion}

\section{Design of renin substrates}

The optimal design of a peptidic substrate for the protease renin foremost depends on a good cleavage site that is available from the N-terminal amino acid sequence of angiotensinogen. ${ }^{13} \mathrm{We}$ chose the first $15 \mathrm{~N}$-terminal amino acids of angiotensinogen (DRVYIHPFHLVIHNE) for detecting the activity of human renin. It should be noted that there is no photophysical constraint on the length of the sequence, in contrast to e.g. the length of FRET substrates. Furthermore, the peptide must be labelled at the $\mathrm{N}$ - and C-terminus for detection in a sandwich ELISA format: one label is required for immobilizing the peptide on the surface of a microtiter plate and the other label for binding a detection system. The hapten 2,4-dichlorophenoxyacetic acid (2,4-D) in combination with aminoundecanoic acid is an optimal $\mathrm{N}$-terminal label for binding a peptide to a microtiter plate coated with an anti-2,4-D-antibody (clone E2/G2). ${ }^{1722}$ Biotin is chosen as the C-terminal label due to its extremely high binding affinity to streptavidin. ${ }^{23}$ The detection system consists of a streptavidinhorseradish peroxidase conjugate that catalyzes a chromogenic reaction.

Positively charged peptides may bind non-specifically to microtiter plates, which can be attributed to cation $-\pi$ interactions between the side chains of lysine, arginine or histidine and polystyrene. $^{\mathbf{1 6 , 2 4}}$ This non-specific binding, however, must be avoided to be able to distinguish between cleaved and intact peptides after a proteolytic reaction. As the peptidic renin substrate (Peptide 1) has a net charge of +3 , peptides flanked by either PEG (Peptide 2) or both PEG and D-glutamate (Peptide 3) were synthesized to compensate for non-specific binding of the core region (Fig. 1A). The peptides were diluted serially on antibody-coated as well as uncoated microtiter plates (Fig. 1B-D) (a) to optimize the concentration of the coating antibody and (b) to find the peptide concentration that yields a high antibody-mediated signal without non-specific surface binding. Non-specific binding to microtiter plates is evident at high peptide concentrations and increases the signal intensity in addition to antibody-mediated binding. Peptide 3 (Fig. 1D) displays the lowest non-specific binding, which can be well separated from antibody-mediated binding. In general, peptide concentrations below $5 \mathrm{nM}$ did not result in non-specific binding. Thus, a constant peptide concentration of $5 \mathrm{nM}$ was employed in the sandwich ELISA for detecting the proteolytic activity of renin.

\section{Renin assay}

Both renin and the peptidic substrate are free in solution (homogeneous assay) to avoid surface effects on the enzyme reaction. The proteolytic activity of renin separates the $\mathrm{N}$ - and $\mathrm{C}$ terminal label of the peptide. With increasing renin activity in a sample, the ratio between intact and cleaved peptides decreases. Serial dilutions of renin in defined peptide solutions (10 nM) lead from samples that contain only cleaved peptides over mixtures to samples that contain only intact peptides. After transferring each sample to an antibody-coated microtiter plate, both cleaved and intact peptides are immobilized proportionally via their N-terminal 2,4-D label. An ELISA-signal, however, is generated only by the biotin label of the intact peptide. As the signal intensities in a well are affected by the experimental - in particular coating - conditions, the intact peptide was used as a reference signal to obtain ratiometric measurements that are essentially independent of absolute signal intensities. ${ }^{25,26}$ The ratio of the signal after renin incubation to the reference signal thus defines the degree of proteolytic degradation.

For data analysis according to Michaelis-Menten kinetics, usually steady-state conditions are given by an excess of substrate over enzyme ([S] $\gg[\mathrm{E}])$. Due to the very high sensitivity of peptide detection using the sandwich ELISA, peptide concentrations lower than $10 \mathrm{nM}$ can be detected. The renin concentration, by contrast, must be high enough for a detectable turnover (up to $12.5 \mathrm{nM}$, Fig. 2), which seems to violate the

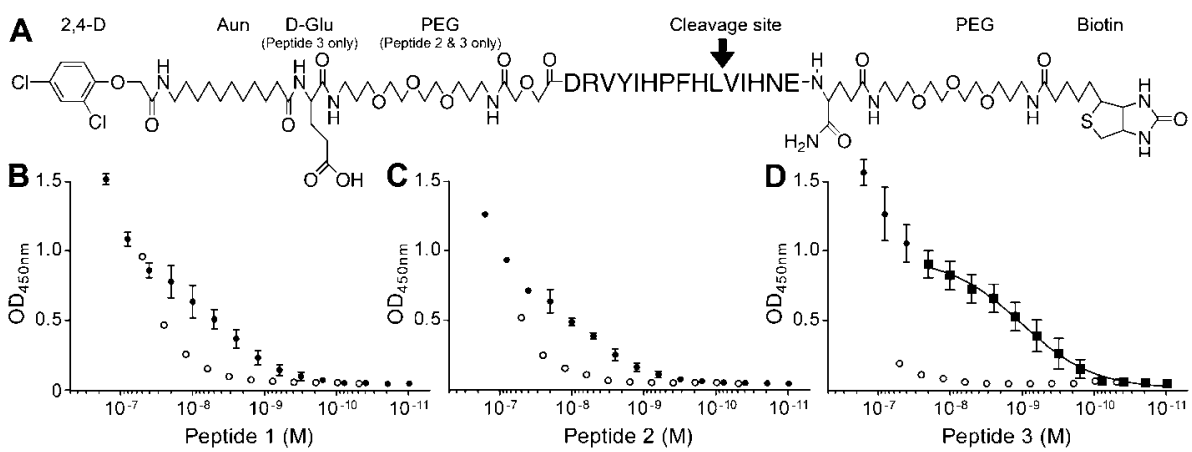

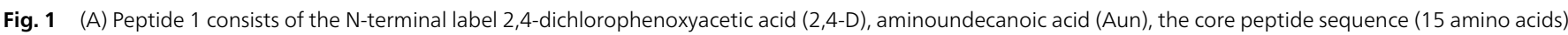

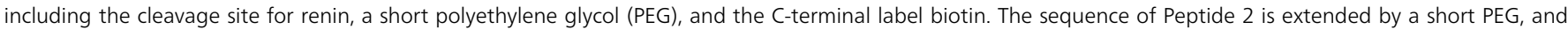

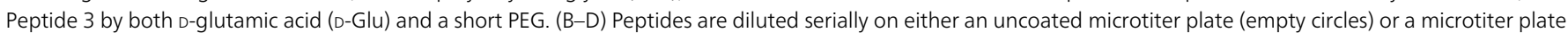

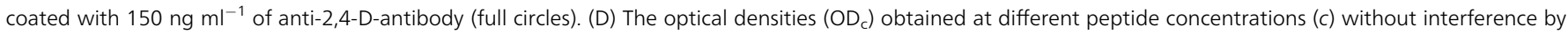

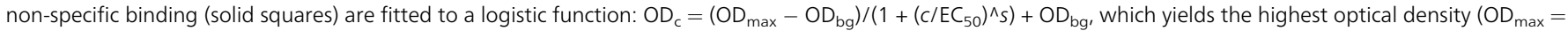

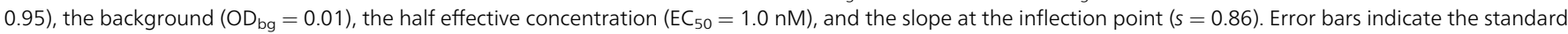
deviation of at least three measurements. 

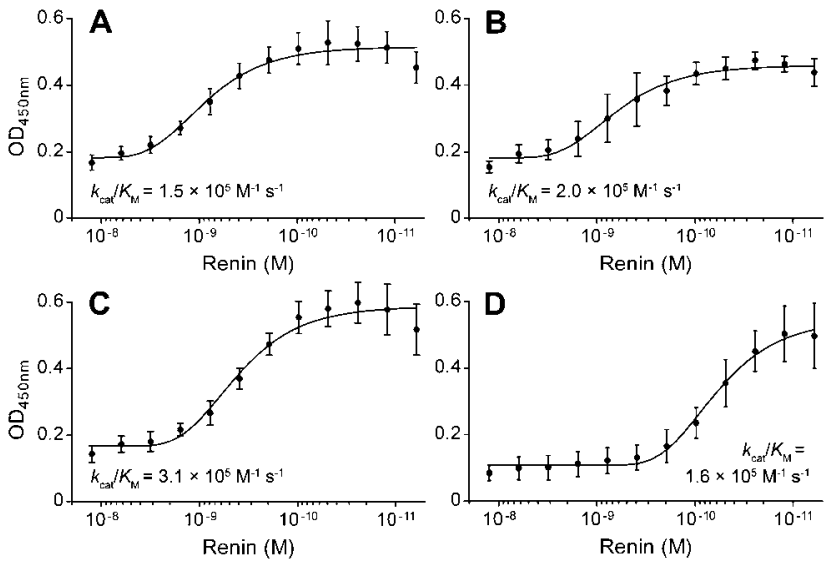

Fig. 2 Proteolytic degradation of Peptide 1 (A), Peptide 2 (B) and Peptide 3 (C and $D)$ by human renin. Dilution series of renin were applied to the peptides in solution (10 nM) for either $90 \mathrm{~min}(\mathrm{~A}-\mathrm{C})$ or $20 \mathrm{~h}(\mathrm{D})$ at $37^{\circ} \mathrm{C}$. After terminating the enzyme reaction by a two-fold concentrated inhibitor solution, the peptides ( 5 $\mathrm{nM}$ ) were detected using a sandwich ELISA. The data (four measurements; the error bars indicate the standard deviation) were fitted to eqn (2). The strongest signal response of $\mathrm{OD}_{450 \mathrm{~nm}}$ to varying renin concentrations is observed in the testmidpoint, which is used to calculate $k_{\text {cat }} / K_{\mathrm{M}}$.

steady-state approximation. Segel pointed out, however, that the steady-state approximation also holds with $[\mathrm{S}]+K_{\mathrm{M}} \gg[\mathrm{E}] .{ }^{27}$ As $K_{\mathrm{M}}$ of good peptidic renin substrates lies in the range of 0.5 to $1 \mu \mathrm{M},{ }^{13}$ the steady-state approximation is valid for the new renin assay.

The integrated Michaelis-Menten equation describes the progress of the enzyme reaction:

$$
K_{\mathrm{M}} \times \ln \frac{[\mathrm{S}]_{0}}{[\mathrm{~S}]}+[\mathrm{S}]_{0}-[\mathrm{S}]=k_{\text {cat }} \times[\mathrm{E}] \times t
$$

where [S] is the substrate concentration ( 0 indicates the initial substrate concentration/intact peptide), [E] the enzyme concentration, $t$ the time, and $K_{\mathrm{M}}$ and $k_{\text {cat }}$ are the kinetic constants. [S] can be replaced by the background corrected optical density (OD) of the ELISA measurement and the reference signal $[\mathrm{S}]_{0}$ is given by $\mathrm{OD}_{\max }$.

Under the conditions used for the renin assay ([S] $\ll K_{\mathrm{M}}$ ), eqn (1) reduces to a pseudo-first order reaction:

$$
\mathrm{OD}=\left(\mathrm{OD}_{\max }-\mathrm{OD}_{\mathrm{bg}}\right) \times \mathrm{e}^{\left(-t[\mathrm{E}] \frac{k_{\mathrm{cat}}}{K_{\mathrm{M}}}\right)}+\mathrm{OD}_{\mathrm{bg}}
$$

which yields the second order rate constant $k_{\text {cat }} / K_{\mathrm{M}}$ as a regression parameter. $k_{\text {cat }} / K_{\mathrm{M}}$ is the most accurate kinetic constant for characterizing a protease's specificity for a substrate. ${ }^{28}$ While it is common to measure the reaction progress after various time intervals, eqn (2) also allows for varying the enzyme concentration at constant incubation times. This approach is more favourable when carrying out kinetic experiments in a highly parallel way using a sandwich ELISA. ${ }^{16}$

Incubating Peptide 1, 2 and 3 for $90 \mathrm{~min}$ with $10 \mathrm{nM}$ to $10 \mathrm{pM}$ of human renin resulted in a continuous transition in OD from completely degraded peptides $\left(\mathrm{OD}_{\mathrm{bg}}\right)$ to intact peptides $\left(\mathrm{OD}_{\max }\right)$ that was used to calculate $k_{\text {cat }} / K_{M}$ according to eqn (2) (Fig. 2). Structural modifications in the flanking region of the 15 amino
Table 1 Renin assays based on synthetic substrates

\begin{tabular}{lcc}
\hline Method & Sequence motif & $\begin{array}{l}k_{\text {cat }} / K_{\mathrm{M}} \\
\left(\mathrm{M}^{-1} \mathrm{~s}^{-1}\right)\end{array}$ \\
\hline $\begin{array}{l}\text { ELISA-based renin assay } \\
\text { Radioimmunoassay }^{37}\end{array}$ & DRVYIHPFHL/VIHNE(15 aa) & 308000 \\
HPLC $^{38}$ & DRVYIHPFHL/VIHN (14 aa) & 250000 \\
FRET(DNP/Amp) $^{13}$ & DRVYIHPFHL/VIHS (14 aa) & $180000^{b}$ \\
FRET(DNP/Amp) ${ }^{13}$ & DRVYIHPFHL/VIH (13 aa) & 181000 \\
FRET(EDANS/DABCYL) $)^{c, 13}$ & KHPFHL/VIH (9 aa) & 352000 \\
${ }^{a}$ Present study. ${ }^{b}$ Estimated from $K_{\mathrm{M}}=8.4 \mu \mathrm{M}$ and $V_{\text {max }}=11 \mu \mathrm{mol}$ \\
angiotensin I made per h per mg renin. ${ }^{38}{ }^{c}$ Commercial substrate.
\end{tabular}

acid-long core peptide (see Fig. 1A) had some effect on $k_{\text {cat }} / K_{\mathrm{M}}$. Peptide 3, which was the best candidate with respect to low nonspecific binding, also yielded the highest $k_{\text {cat }} / K_{\mathrm{M}}$ of $308000 \mathrm{M}^{-1}$ $\mathrm{s}^{-1}$ (Fig. 2B). After a prolonged incubation time of $20 \mathrm{~h}$, however, this value appeared to decrease to $159000 \mathrm{M}^{-1} \mathrm{~S}^{-1}$ (Fig. 2D), which can be attributed to a loss of enzyme activity. Using a relatively short and constant incubation time of $90 \mathrm{~min}$ instead of time series, thus, is a simple way to avoid a loss of enzyme activity.

The double-labelled renin substrates employed in the ELISAbased assay yielded comparable results for $k_{\text {cat }} / K_{\mathrm{M}}$ as FRET-based substrates of similar length (Table 1). Paschalidou et al. ${ }^{13}$ characterized the influence of the peptide length in FRET-based substrates on $k_{\text {cat }} / K_{\mathrm{M}}$ in detail. When they extended the peptide sequence one amino acid at a time, $k_{\text {cat }} / K_{\mathrm{M}}$ increased successively but an optimum was not reached with a length of 13 amino acids (181000 $\mathrm{M}^{-1} \mathrm{~s}^{-1}$ ). As the quenching efficiency decreases with the sixth power of the distance between the donor and acceptor, the FRET substrate comprising 13 amino acids resulted in a signal to background ratio of only five and thus was classified as rather insensitive. Longer peptides are in general not practical. To circumvent this length limitation, the amino acid sequence was modified in search of optimal shorter substrates (Table 1).

\section{Analysis of plasma samples}

As the new protease assay is robust even in raw intestinal fluids, ${ }^{\mathbf{1 6 , 2 9}}$ it was applied to analyzing the activity of renin in raw murine plasma. Experimental details are given in the ESI. $\nmid$ Mice were treated intraperitoneally with isoproterenol to stimulate the production of renin, and one hour later plasma from treated and untreated mice was collected. ${ }^{6}$ Using a commercial radioimmunoassay and angiotensinogen as a substrate, it was shown that the renin activity was 100 -fold higher in treated than in untreated mice. In the ELISA-based renin assay, however, both plasma samples showed the same activity on murine peptidic substrates, which can be explained by the nonspecific activity of other proteases than renin in plasma. The three-dimensional conformation of the large $(50 \mathrm{kDa})$ natural substrate angiotensinogen protects the cleavage site from various other proteases present in blood. Here, we have presented experimental evidence for the non-specific activity of plasma on synthetic renin substrates that has been described only marginally in previous literature reports. ${ }^{15,30}$ 

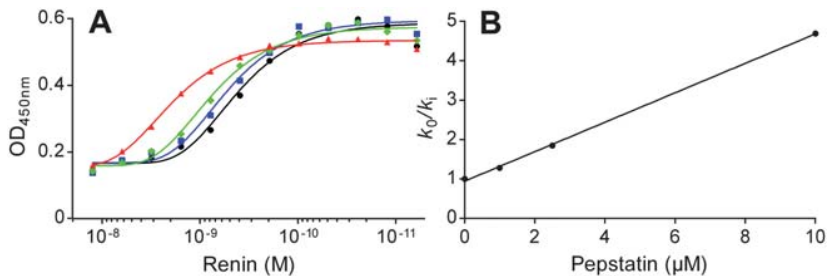

Fig. 3 Inhibition of human renin by pepstatin. (A) Renin was diluted serially on the peptide without inhibitor (black circles), and in the presence of $1 \mu \mathrm{M}$ (blue squares), $2.5 \mu \mathrm{M}$ (green diamonds) and $10 \mu \mathrm{M}$ (red triangles) of pepstatin. (B) The rate constants were normalized according to eqn (5), and the slope of the linear regression yielded $K_{\mathrm{i}}=2.7 \mu \mathrm{M}\left(r^{2}=0.9994\right)$. Data points represent the mean of at least three measurements.

\section{Inhibition of renin}

Due to the key role of renin in the regulation of blood pressure, it is essential to identify potent renin inhibitors. ${ }^{4,31,32}$ The renin assay can be adapted to inhibitor screening by diluting renin serially on a fixed mixture of peptidic substrate and competitive inhibitor, incubating for $90 \mathrm{~min}$ at $37{ }^{\circ} \mathrm{C}$, and detecting the proteolytic reaction on an antibody-coated microtiter plate. The inhibition of renin can then be analyzed based on the integrated Michaelis-Menten equation for competitive inhibition:

$$
K_{\mathrm{M}} \times\left(1+\frac{[\mathrm{I}]}{K_{\mathrm{i}}}\right) \times \ln \frac{[\mathrm{S}]_{0}}{[\mathrm{~S}]}+[\mathrm{S}]_{0}-[\mathrm{S}]=k_{\text {cat }} \times[\mathrm{E}] \times t
$$

where [I] is the inhibitor concentration and $K_{\mathrm{i}}$ is the inhibition constant. Under pseudo-first order reaction conditions $\left([\mathrm{S}] \ll K_{\mathrm{M}}\right)$, the rate constant $k_{0}=[\mathrm{E}] k_{\text {cat }} / K_{\mathrm{M}}$ of the uninhibited reaction in eqn (2) changes to the rate constant $k_{\mathrm{i}}$ of the inhibited reaction:

$$
k_{\mathrm{i}}=[\mathrm{E}] \frac{k_{\mathrm{cat}}}{K_{\mathrm{M}}\left(1+\frac{[\mathrm{I}]}{K_{\mathrm{i}}}\right)}
$$

Using various inhibitor concentrations and standardizing to the uninhibited reaction $\left(k_{0}\right)$ yields a linear equation:

$$
\frac{k_{0}}{k_{\mathrm{i}}}=1+\frac{[\mathrm{I}]}{K_{\mathrm{i}}}
$$

Starting from a $y$-intercept of 1 without inhibitor, $k_{0} / k_{\mathrm{i}}$ increases linearly with the inhibitor concentration, and $K_{\mathrm{i}}$ can be obtained from the slope.

The microbial peptide pepstatin (isovaleryl-L-valyl-L-valyl-4amino-3-hydroxy-6-methylheptanoyl-L-alanyl-4-amino-3-hydroxy6-methylheptanoic acid) ${ }^{33}$ is a competitive inhibitor of renin ${ }^{18,34}$ and other aspartyl proteases. ${ }^{35}$ Pepstatin is a well-characterized transition state analog of aspartyl protease substrates that constitutes a good model system for the inhibition of renin. Using the ELISA-based renin assay, a $K_{\mathrm{i}}$ of $2.7 \mu \mathrm{M}$ pepstatin was calculated for the inhibition of human renin (Fig. 3). The excellent linearity of $k_{0} / k_{\mathrm{i}}$ with the inhibitor concentration shows that it is sufficient to use only a single inhibitor concentration to determine $K_{\mathrm{i}}$ accurately if $k_{\text {cat }} / K_{\mathrm{M}}$ of the uninhibited reaction is known. Literature reports of $K_{\mathrm{i}}$ are also in the lower micromolar range, but vary because the inhibition by pepstatin is influenced by the $\mathrm{pH}$, the substrate, and other experimental conditions. For example, when angiotensinogen was used as the substrate, the $K_{\mathrm{i}}$ was $1.4 \mu \mathrm{M}$ pepstatin at $\mathrm{pH}$ 5.7, but $16 \mu \mathrm{M}$ at $\mathrm{pH} 7.4 .^{19}$ When a synthetic tetradecapeptidic substrate was used at $\mathrm{pH} 6.5$, a $K_{\mathrm{i}}$ of $15 \mu \mathrm{M}$ was calculated. ${ }^{20}$

\section{Conclusions}

The variations in the determination of $K_{\mathrm{i}}$ among literature values highlight the need for well-defined experimental conditions to obtain comparable results from inhibitor screening. Here, we have presented a simple and robust kinetic analysis that yields excellent kinetic values for the activity of renin and its inhibitors. In contrast to the widely used FRET-substrates, the new renin analysis is not influenced by the absolute signal intensity, optical interference in renin samples, and the length of the renin substrates. The new kinetic analysis can be easily adapted to inhibitor screening of other medically important proteases. For example, the renin-pepstatin interaction can serve as a model for the inhibition of the aspartyl-protease from the human immunodeficiency virus (HIV), ${ }^{36}$ which is a major drug target for the treatment of HIV.

\section{Abbreviations}

ACE

$\mathrm{AT}_{1}$ receptor

Aun

2,4-D

RAS
Angiotensin-converting enzyme; Angiotensin II receptor subtype-1; Aminoundecanoic acid; 2,4-dichlorophenoxyacetic acid; Renin-angiotensin system.

\section{Acknowledgements}

The author thanks Dr Niels Röckendorf and PD Dr Andreas Frey from the Division of Mucosal Immunology and Diagnostics, Research Center Borstel, Germany, for synthesizing peptidic substrates, Dr Milan Fránek from the Department of Analytical Biotechnology, Veterinary Research Institute in Brno, Czech Republic, for providing the antibody clone E2/G2, Prof. Armin Kurtz from the Institute of Physiology, University of Regensburg, Germany, for financial support, Prof. Frank Schweda from the same institute for providing murine plasma samples, and Robert Götz for technical support.

\section{Notes and references}

1 H. Castrop, K. Höcherl, A. Kurtz, F. Schweda, V. Todorov and C. Wagner, Physiology of kidney renin, Physiol. Rev., 2010, 90, 607.

2 N. D. L. Fisher and N. K. Hollenberg, Is there a future for renin inhibitors?, Expert Opin. Invest. Drugs, 2001, 10, 417.

$3 \mathrm{M}$. W. Taal and B. M. Brenner, Renoprotective benefits of RAS inhibition: from ACEI to angiotensin II antagonists, Kidney Int., 2000, 57, 1803.

4 A. H. Gradman, R. Pinto and R. Kad, Current concepts: renin inhibition in the treatment of hypertension, Curr. Opin. Pharmacol., 2008, 8, 120. 
5 E. Haber, T. Koerner, L. B. Page, B. Kliman and A. Purnode, Application of a radioimmunoassay for angiotensin I to the physiologic measurements of plasma renin activity in normal human subjects, J. Clin. Endocrinol. Metab., 1969, 29, 1349.

6 F. Aldehni, R. Tang, K. Madsen, M. Plattner, A. Schreiber, U. G. Friis, H. K. Hammond, P. L. Han and F. Schweda, Stimulation of renin secretion by catecholamines is dependent on adenylyl cyclase 5 and 6, Hypertension, 2011, 57, 460.

7 V. F. Fredline, E. M. Kovacs, P. J. Taylor and A. G. Johnson, Measurement of plasma renin activity with use of HPLCelectrospray-tandem mass spectrometry, Clin. Chem., 1999, 45, 659.

8 A. Reinharz and M. Roth, Studies on renin with synthetic substrates, Eur. J. Biochem., 1969, 7, 334.

9 K. Murakami, T. Ohsawa, S. Hirose, K. Takada and S. Sakakibara, New fluorogenic substrates for renin, Anal. Biochem., 1981, 110, 232.

10 N. Nakamuraimajo, S. Satomura, S. Matsuura and K. Murakami, Renin assay using a fluorogenic substrate and high-performance liquid-chromatography, Clin. Chim. Acta, 1992, 211, 47.

11 M. C. F. Oliveira, I. Y. Hirata, J. R. Chagas, P. Boschcov, R. A. S. Gomes, A. F. S. Figueiredo and L. Juliano, Intramolecularly quenched fluorogenic peptide substrates for human renin, Anal. Biochem., 1992, 203, 39.

12 G. T. Wang, C. C. Chung, T. F. Holzman and G. A. Krafft, A continuous fluorescence assay of renin activity, Anal. Biochem., 1993, 210, 351.

13 K. Paschalidou, U. Neumann, B. Gerhartz and C. Tzougraki, Highly sensitive intramolecularly quenched fluorogenic substrates for renin based on the combination of $\mathrm{L}-2$ amino-3-(7-methoxy-4-coumaryl)propionic acid with 2,4dinitrophenyl groups at various positions, Biochem. J., 2004, 382, 1031.

14 P. R. Selvin, The renaissance of fluorescence resonance energy transfer, Nat. Struct. Biol., 2000, 7, 730.

15 M. A. Ondetti and D. W. Cushman, Enzymes of the reninangiotensinogen system and their inhibitors, Annu. Rev. Biochem., 1982, 51, 283.

16 H. H. Gorris, S. Bade, N. Röckendorf, E. Albers, M. A. Schmidt, M. Franek and A. Frey, Rapid profiling of peptide stability in proteolytic environments, Anal. Chem., 2009, 81, 1580.

17 H. H. Gorris, S. Bade, N. Röckendorf, M. Franek and A. Frey, Pushing antibody-based labeling systems to higher sensitivity by linker-assisted affinity enhancement, Bioconjugate Chem., 2011, 22, 1619.

18 F. Gross, J. Lazar and H. Orth, Inhibition of the reninangiotensinogen reaction by pepstatin, Science, 1972, 175, 656.

19 T. T. Guyene, C. Devaux, J. Menard and P. Corvol, Inhibition of human-plasma renin-activity by pepstatin, J. Clin. Endocrinol. Metab., 1976, 43, 1301.

20 M. Eid, G. Evin, B. Castro, J. Menard and P. Corvol, New renin inhibitors homologous with pepstatin, Biochem. J., 1981, 197, 465.
21 M. Franek, V. Kolar, M. Granatova and Z. Nevorankova, Monoclonal ELISA for 2,4-dichlorophenoxyacetic acid: characterization of antibodies and assay optimization, $J$. Agric. Food Chem., 1994, 42, 1369.

22 S. Bade, N. Röckendorf, M. Franek, H. H. Gorris, B. Lindner, V. Olivier, K. J. Schaper and A. Frey, Biolabeling with 2,4dichlorophenoxyacetic acid derivatives: the 2,4-D tag, Anal. Chem., 2009, 81, 9695.

23 N. M. Green, Avidin and streptavidin, Methods Enzymol., 1990, 184, 51.

24 J. C. Ma and D. A. Dougherty, The cation-pi interaction, Chem. Rev., 1997, 97, 1303.

25 X. D. Wang, H. H. Gorris, J. A. Stolwijk, R. J. Meier, D. B. M. Groegel, J. Wegener and O. S. Wolfbeis, Selfreferenced RGB colour imaging of intracellular oxygen, Chem. Sci., 2011, 2, 901.

26 H. H. Gorris, R. Ali, S. M. Saleh and O. S. Wolfbeis, Tuning the dual emission of photon-upconverting nanoparticles for ratiometric multiplexed encoding, Adv. Mater., 2011, 23, 1652.

27 L. A. Segel, On the validity of the steady state assumption of enzyme kinetics, Bull. Math. Biol., 1988, 50, 579.

28 F. E. Brot and M. L. Bender, Use of the specificity constant of alpha-chymotrypsin, J. Am. Chem. Soc., 1969, 91, 7187.

29 S. Bade, H. H. Gorris, S. Koelling, V. Olivier, P. Zabel and A. Frey, Quantitation of major protein constituents of murine intestinal fluid, Anal. Biochem., 2010, 406, 157.

30 J. C. Cornette, D. B. Evans, A. M. Furlong and S. K. Sharma, Renin activity determination using human plasma as a substrate, Anal. Biochem., 1987, 163, 93.

31 M. Szelke, B. Leckie, A. Hallett, D. M. Jones, J. Sueiras, B. Atrash and A. F. Lever, Potent new inhibitors of human renin, Nature, 1982, 299, 555.

32 J. M. Wood, J. L. Stanton and K. G. Hofbauer, Inhibitors of renin as potential therapeutic agents, J. Enzyme Inhib., 1987, 1, 169.

33 H. Morishima, T. Takita, T. Aoyagi, T. Takeuchi and H. Umezawa, The structure of pepstatin, J. Antibiot., 1970, 23, 263.

34 R. P. Miller, C. W. Wilson, E. Devito and C. J. Poper, Renin inhibition by pepstatin, Biochem. Pharmacol., 1972, 21, 2941.

35 J. Marciniszyn, J. A. Hartsuck and J. Tang, Mode of inhibition of acid proteases by pepstatin, J. Biol. Chem., 1976, 251, 7088.

36 K. von der Helm, L. Gürtler, J. Eberle and F. Deinhardt, Inhibition of HIV replication in cell culture by the specific aspartic protease inhibitor pepstatin A, FEBS Lett., 1989, 247, 349.

37 F. Cumin, D. Le-Nguyen, B. Castro, J. Menard and P. Corvol, Comparative enzymatic studies of human renin acting on pure natural or synthetic substrates, Biochim. Biophys. Acta, 1987, 913, 10.

38 M. Poe, J. K. Wu, T. Y. Lin, K. Hoogsteen, H. G. Bull and E. E. Slater, Renin cleavage of a human kidney renin substrate analogous to human angiotensinogen, H-AspArg-Val-Tyr-lle-His-Pro-Phe-His-Leu-Val-Ile-His-Ser-OH, that is human renin specific and is resistant to cathepsin D, Anal. Biochem., 1984, 140, 459. 